distinguished studies of the Palæozoic rocks, particularly in Wales, his work on sediments, his palæontological researches and the application of geological knowledge to practical problems.

The following awards of medals have been made by the President and the Council of the Royal Society : Copley Medal: Prof. P. M. S. Blackett, professor of physics in the Imperial College of Science and Technology, London, for his outstanding studies of cosmic ray showers and heavy mesons and in the field of palæomagnetism; Rumford Medal: Dr. F. P. Bowden, reader in physical chemistry in the University of Cambridge, for his distinguished work on the nature of friction; Davy Medal: Prof. R. D. Haworth, Firth professor of chemistry and head of the Chemistry Department in the University of Sheffield, for his distinguished contributions to the chemistry of natural products, particularly those containing heterocyclic systems; Darwin Medal: Dr. J. S. Huxley, for his distinguished contributions to the study and theory of evolution; Hughes Medal : Lord Cherwell, lately professor of experimental philosophy in the University of Oxford, for his distinguished work in many fields : the meltingpoint formula and theory of specific heats ; ionization of stars; meteors and temperature inversion in the stratosphere.

\section{The American Geographical Society: Medal Awards}

THe Council of the American Geographical Society has made the following awards : Cullum Geographical Medal : Prof. J. Russell Smith, emeritus professor of economic geography in Columbia University, and author of several books on North America that have become classics in their field; Charles P. Daly Medal : Prof. Raoul Blanchard, long associated with the University of Grenoble, whose monumental work on the Alps will be completed with the appearance of the twelfth volume; David Livingstone Centenary Medal : Prof. George McCutcheon McBride, emeritus professor of geography in the University of California at Los Angeles, a leading authority on problems of economic and cultural geography in Latin America.

\section{The National Zoological Park, Washington :} Dr. William M. Mann

Dr. William M. ManN, who has been director of the National Zoological Park at Washington for thirty-one years, retired on October 31. Dr. Mann, who recently reached the statutory retirement age of seventy, was the fifth director the National Zoological Park has had since it was established by the Smithsonian Institution in 1889. He began his career in 1916 as an entomologist with the Bureau of Entomology, United States Department of Agriculture. It is widely recognized that under Dr. Mann's direction the Washington zoo has become one of the best and most representative collections of living animals in the world. The physical equipment of the zoo also has steadily improved, and during Dr. Mann's administration four modern exhibition buildings were added and others are planned. Dr. Mann is one of the world's greatest authorities on ants. $\mathrm{He}$ has collected and studied these insects around tho globe, and only last year he presented to the Smithsonian Institution his huge personal collection of these insects, numbering more than 117,000 specimens. For the zoo Dr. Mann has made trips to many foreign lands to obtain live animals for the collection. For example, in 1926 he headed the Smithsonian-Chrysler Expedition to East Africa, in 1937 a National Geographic Society Expedition to the East Indies, and in 1940 the Smithsonian-Firestone Expedition to Liberia. He will continue his association with the Smithsonian in the capacity of honorary research associate, the Institution's highest honorary scientific designation. Dr. Theodore H. Reed, of Portland, Oreg., who has held the post of chief veterinarian of the zoo since July 1955, has been appointed acting director of the National Zoological Park.

\section{The D.S.I.R. Research Council}

The Department of Scientific and Industrial Research Act, 1956, has now come into force, and the composition of the new Council of the Depart. ment is: Sir Harry Jephcott, chairman, Glaxo Laboratories, Ltd. (chairman); Sir Eric Ashby, president and vice-chancellor, The Queen's University of Belfast; Prof. C. E. H. Bawn, Grant-Brunner professor of inorganic and physical chemistry, University of Liverpool ; Sir Hugh Beaver, managing director, Arthur Guinness, Son and Co., Ltd. ; Prof. P. M. S. Blackett, professor of physics, Imperial College of Science and Technology, University of London; Mr. H. Douglass, general secretary, Iron and Steel Trades Confederation; Sir Walter Drum. mond, a director of George Angus and Co., Ltd., and also Smith's Dock Co., Ltd.; Mr. W. L. Heywood, general secretary, National Union of Dyers, Bleachers and Textile Workers; Dr. Willis Jackson, director of research and education, Metropolitan-Vickers Electrical Co., Ltd.; Sir Philip Johnson, deputy chairman, R. and W. Hawthorn, Leslie and Co., Ltd.; Prof. E. A. G. Robinson, professor of economics, University of Cambridge. Dr. H. W. Melville, secretary of the present Advisory Council, will be secretary of the new Council. Payment of $£ 1,000$ a year to the chairman and $£ 750$ a year to each member of the Council is authorized under Section $2(5)$ of the Act.

\section{Large Heavy-water Reactor at Harwell}

BrITaIN's first large heavy-water reactor, DIDO, built for testing materials and making powerful radioactive isotopes, has started operating at Harwell. DIDO will develop about ten megawatts of heat at full power, and its neutron flux will be about $10^{14}$ neutrons per sq. cm. per sec. It is the most powerful experimental reactor in Western Europe. Heavy water is used as the moderator, and the fuel is highly enriched uranium. The reactor will be formally opened by Sir Cyril Hinshelwood, president of the Royal Society, on November 21. The name DIDO is derived from the formula $\mathrm{D}_{2} \mathrm{O}$ for heavy water.

\section{Precautions in handling Radioactive Isotopes}

Paralife to the increasing use of radioactive isotopes by industry, there has been an increase in the demand for advice on the precautions required to ensure safe handling and disposal of radioactive materials, and both the Health Physics Division and the Isotope IDivision's Advisory Service on the Industrial Applications of Radioisotopes of the Atomic Energy Research Establishment, Harwell, have been active in this regard. During 1955 it was decided to supplement the services provided by the Divisions by a series of short courses of instruction on radiological protection, and the first course was held during November 1955 at Harwell. The course 